\title{
Medicina Fluminensis: promotor najmlađih stvaratelja znanosti
}

\author{
Medicina Fluminensis: promoter of the youngest science creators
}

\section{DOSEZI STUDENTSKE SEKCIJE U 2018. GODINI}

Inicijativu za osnivanje Studentske sekcije časopisa Medicina Fluminensis pokrenuli su Glavni i odgovorni urednik te Izvršna urednica, koji su na Prvom međunarodnom biomedicinskom kongresu u Rijeci (BRIK, 2. - 4. studenoga 2017.) prepoznali potencijal, motivaciju, energiju te interes studenata za sve raniju integraciju u svijet znanosti i znanstvenih istraživanja. Svi ciljevi Studentske sekcije časopisa Medicina Fluminensis zasnivaju se i provode na temelju timskog rada Uredništva, dvaju studentskih predstavnika u Uredničkom odboru i studenata uključenih u znanstveni program Medicinskog fakulteta u Rijeci.

U 2018. godini, prvoj godini postojanja Studentske sekcije časopisa Medicina Fluminensis ostvarena je većina postavljenih ciljeva, uključujući službenu potporu časopisa na znanstvenim skupovima koje organiziraju studenti Medicinskog fakulteta u Rijeci (slika 1) ${ }^{1}$. Na navedenim skupovima provedena je evaluacija i odabir najboljeg izlaganja (tablica 1). Također, s obzirom na to da je jedan od glavnih ciljeva Studentske sekcije uspostaviti sustav znanstvene edukacije za studente, uspješno je održana i prva radionica „Kako napisati dobar prikaz slučaja“ (slika 2). Prikaz slučaja vrsta je znanstvenog članka s kojim se studenti najčešće prvo susreću kada se odluče zakoračiti u svijet znanosti. U sklopu radionice polaznici su se imali prilike pobliže upoznati s vrstama znanstvenih djela, strukturom i smjernicama za pisanje prikaza slučaja (engl. CARE guidelines) te postupkom pretraživanja literature ${ }^{2}$. Nakon dvodnevne edukativne radionice svakom studentu bio je dodijeljen mentor iz Kliničkog bolničkog centra Rijeka te pružena prilika da prikaz slučaja napiše na temelju stvarnog primjera iz kliničke prakse. Naposljetku, naš je cilj bio publicirati dodatni broj časopisa posvećen Studentskoj sekciji u kojem bi bili objavljeni prvoautorski studentski znanstveni članci. No, zbog velikog interesa, broja i kvalitete pristiglih znanstvenih članaka, odlučili smo svojim studentima posvetiti ovaj redoviti tematski broj, koji u budućnosti ima potencijal postati jednogodišnji dodatni broj. Navedeno izdanje prvo je ovakvog oblika u Hrvatskoj.

http://hrcak.srce.hr/medicina 
TEMATSKI BROJ POSVEĆEN PRVOAUTORSKIM STUDENTSKIM RADOVIMA

U ovom tematskom broju objavljeno je 15 znanstvenih članaka, uključujući in extenso članke odabranih najboljih izlaganja na znanstvenim skupovima u organizaciji studenata Medicinskog fakulteta u Rijeci, najbolje članke odabrane na radionici „Kako napisati dobar prikaz slučaja?“ te članke koji su pristigli po objavljenom pozivu za tematski broj. Kao posebno vrijedan članak ističemo pregledni članak autorice Eme Karmelić u kojem su prvi put na jednom mjestu objedinjene sve studentske znanstvene aktivnosti na Medicinskom fakultetu u Rijeci u obliku povijesnog pregleda.

lako se studenti pri pokušaju objavljivanja prvoautorskih znanstvenih članaka često susreću s predrasudama o svojoj slabijoj kvaliteti, stoga i manje strogim kriterijima za objavu, u našem smo časopisu odlučili studentima pružiti istovjetne uvjete kao i svakom drugom autoru, počevši od postupka prijave, recenzijskog postupka, pa sve do konačne odluke o potencijalnoj objavi. Prednost takvog ravnopravnog odnosa prije svega pridonosi samim studentima, koji na taj način imaju jedinstvenu mogućnost edukacije o suradnji sa znanstvenim časopisima, postupkom evaluacije članka, ali i prepisci s recenzentima, što je specifičan oblik komunikacije u znanosti. Najveća prednost čitavog postupka je u tome što studenti na početku svoje znanstvene karijere o navedenim oblicima znanstvenog ustroja imaju priliku učiti na hrvatskom jeziku, što će im u budućnosti olakšati primjenu usvojenih znanja i vještina, kao i širenje „krugova“ u međunarodnoj znanstvenoj zajednici. S obzirom na navedeno, međunarodni biomedicinski časopisi koji imaju studentske sekcije te ovakvi, nažalost, još uvijek rijetki brojevi posvećeni studentima, od velike su važnosti jer mlade istraživače - studente potiču na nastavak znanstvene aktivnosti i postupno unaprjeđenje svojih kompetencija. Na svakom znanstvenom članku objavljenom u ovom broju koautori su i mentori studenata, pa im zahvaljujemo što studente uključuju u svoja znanstvena istraživanja te na taj način pridonose podizanju kvalitete studentske znanstvene aktivnosti.

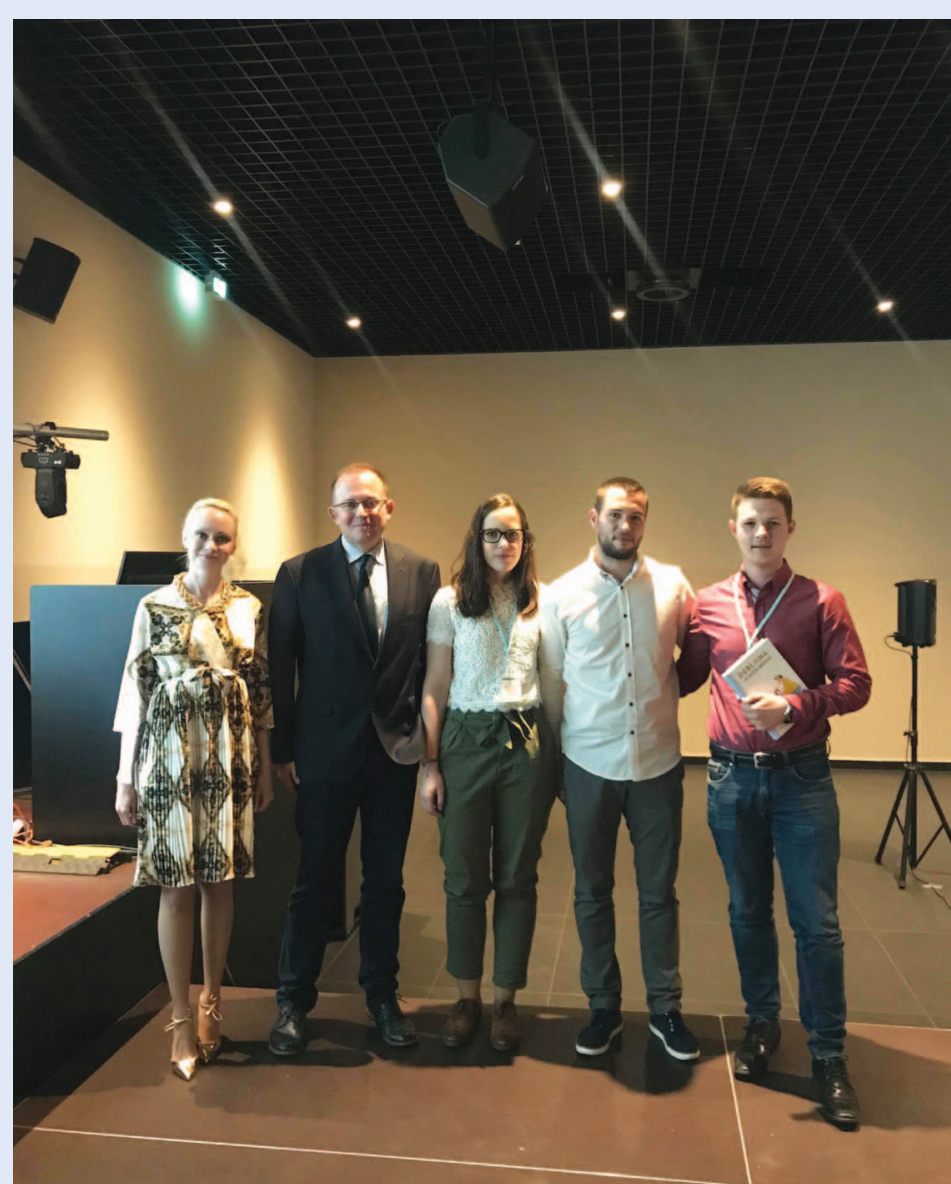

Slika 1. Proglašenje najboljeg izlaganja na Studentskom simpoziju 7. hrvatskog kongresa debljine (redom doc. dr. sc. Nina Pereza, dr. med., prof. dr. sc. Saša Ostojić, dr. med., Marija Krpina - pobjednica, Andrej Belančić, dr. med., Massimo Bembić - pobjednik)

Uz svečanu promociju ovog broja časopisa Medicina Fluminensis u Rijeci u prosincu održat će se i prvi „Znanstveni koktel“ s ciljem kreativnog i konstruktivnog druženja predstavnika časopisa, $\mathrm{Hr}$ vatskoga liječničkog zbora - podružnica Rijeka, Medicinskog fakulteta u Rijeci s mentorima i studentima o mogućnostima daljnjeg razvoja studentske znanstvene aktivnosti. „Znanstveni koktel“ trebao bi postati novi cjelogodišnji program popularizacije znanosti.

\section{VIZIJA ZA 2019. GODINU}

Medicinski fakultet u Rijeci institucija je s izrazito kvalitetnom znanstvenom produkcijom i infrastrukturom, prepoznatljivim znanstvenim grupama i pojedincima, koji su svojim radom uspostavili centre izvrsnosti i koji vode prestižne projekte na međunarodnoj i domaćoj razini. Kvaliteta, odjek i utjecaj sveukupnih znanstvenih publikacija koje 
Tablica 1. Najbolja izlaganja na znanstvenim skupovima u organizaciji studenata Medicinskog fakulteta u Rijeci izabrana prema kriterijima Uredništva časopisa Medicina Fluminensis u 2017./2018. akademskoj godini

\begin{tabular}{|c|c|c|c|}
\hline Naziv znanstvenog skupa & $\begin{array}{l}\text { Datum i mjesto } \\
\text { održavanja } \\
\text { znanstvenog skupa }\end{array}$ & Autori izlaganja & Naslov izlaganja \\
\hline $\begin{array}{l}\text { Prvi međunarodni } \\
\text { biomedicinski kongres u Rijeci } \\
\text { (BRIK 2017.) }\end{array}$ & $\begin{array}{l}\text { 2. - 4. studenoga } \\
\text { 2017., Rijeka/Poreč }\end{array}$ & $\begin{array}{l}\text { Terezija Berlančić, Vedran } \\
\text { Pašara, Lada Zibar }\end{array}$ & $\begin{array}{l}\text { Spontaneous HbsAg seroconversion } \\
\text { after a long lasting infection in a chronic } \\
\text { hemodialysis patient }\end{array}$ \\
\hline $\begin{array}{l}\text { Treći kongres hitne medicine s } \\
\text { međunarodnim sudjelovanjem }\end{array}$ & $\begin{array}{l}\text { 23. - 25. ožujka 2018., } \\
\text { Rijeka }\end{array}$ & Kristina Kampić, David Bonifačić & $\begin{array}{l}\text { The importance of scales for treating } \\
\text { brain stroke }\end{array}$ \\
\hline $\begin{array}{l}\text { Studentski kongres } \\
\text { neuroznanosti (NeuRi 2018.) }\end{array}$ & $\begin{array}{l}\text { 20. - 22. travnja } \\
\text { 2018., Rijeka/Rab }\end{array}$ & $\begin{array}{l}\text { Ajla Muratović, Tarik } \\
\text { Altumbabić, Larisa Kovačević }\end{array}$ & $\begin{array}{l}\text { Correlation of work ability and degree } \\
\text { of depression in patients with epilepsy }\end{array}$ \\
\hline $\begin{array}{l}\text { Studentski simpozij } 7 . \\
\text { hrvatskog kongresa debljine }\end{array}$ & $\begin{array}{l}\text { 27. travnja 2018., } \\
\text { Opatija }\end{array}$ & $\begin{array}{l}\text { Marija Krpina, Lucija Knez, } \\
\text { Andrej Belančić, Paula Georgev, } \\
\text { Martina Demaria, Manuela } \\
\text { Avirović, Marina Kosmat, Franjo } \\
\text { Lovasić, Elvira Mustać } \\
\text { Massimo Bembić, Marko } \\
\text { Samardžija, Tea Štimac }\end{array}$ & $\begin{array}{l}\text { Connection between invasive breast } \\
\text { cancer characteristics and adipose } \\
\text { tissue quantity and distribution in } \\
\text { postmenopausal women }\end{array}$ \\
\hline $\begin{array}{l}\text { Deveti studentski kongres } \\
\text { Prehrana i klinička dijetoterapija }\end{array}$ & $\begin{array}{l}\text { 8. - 10. lipnja 2018., } \\
\text { Rijeka }\end{array}$ & $\begin{array}{l}\text { Dorotea Matešić, Valerija } \\
\text { Majetić Germek, Olivera } \\
\text { Koprivnjak }\end{array}$ & $\begin{array}{l}\text { Sol, šećer i zasićene masti u dvopeku na } \\
\text { hrvatskom tržištu }\end{array}$ \\
\hline
\end{tabular}

Medicinski fakultet Sveučilišta u Rijeci i znanstveno-stručni časopis Medicina Fluminensis, uz potporu Znanstvenog odbora svih studenata

$$
\text { organiziraju radionicu }
$$

\section{KAKO NAPISATI DOBAR PRIKAZ SLUČAJA?}

Poštovani studenti integriranog preddiplomskog i diplomskog studija Medicina i Dentalna medicina,

pozivamo Vas na prijavu za edukativnu i kreativnu radionicu koja će se održati 09. i 10. ožujka 2018., u biblioteci Zavoda za biologiju i medicinsku genetiku.

Osnovni cilj radionice je omogućiti stjecanje osnovih znanja i vještina pripreme i pisanja prikaza slučaja, vrste znanstvenog članka s kojim se studenti najčešće prvo susreću tijekom svojeg znanstvenog rada. Nakon dvodnevne edukativne radionice, svakom će polazniku biti dodijeljen mentor i stvarni primjer slučaja iz kliničke medicine te pružena prilika da napiše znanstveni članak.

Dodatne pogodnosti za polaznike uključuju:

- tri najbolje napisana prikaza slučaja dobit će priliku za objavu u časopisu Medicina Fluminensis

- svim polaznicima bit će omogućen popust na kotizaciju u iznosu od $20 \%$ i aktivno sudjelovanje na drugom Međunarodnom biomedicinskom studentskom kongresu (BRIK 2018)

Uvjeti:

- rok za prijavu je 15 . veljače 2018

- rok za prijavu je 15. veljače 2018 .

- kotizacija iznosi 30 kuna

- broj polaznika ograničen je na 12 studenata (11 Medicina + 1 Dentalna medicina)

(u slučaju većeg broja prijavljenih, polaznike će odabrati Organizacijski odbor prema prispjelim prijavnicama)

Slika 2. Program radionice „Kako napisati dobar prikaz slučaja?“
Organizacijski odbor:

doc. dr. sc. Nina Pereza, Izvršna urednica Medicine Fluminensis

prof. dr. sc. Saša Ostojić, Glavni i odgovorni urednik Medicine Fluminensis

Andrej Belančić, studentska sekcija Medicine Fluminensis

Damir Vučinić, studentska sekcija Medicine Fluminensis

Maja Ploh, predsjednica Znanstvenog odbora svih studenata

Mentori:

prof. dr. sc. Marija Kaštelan, prof. dr. sc. Damir Miletić, prof. dr. sc. Jelena Roganović, prof. dr. sc. Neda Smiljan Severinski, prof. dr. sc. Vlatka Sotošek Tokmadžić, prof. dr. sc. Toni Valković, prof. dr. sc. Renata Gržić, doc. dr. sc. Dean Markić, doc. dr. sc. Goran Poropat, doc. dr. sc. Arnela Redžović, doc. dr. sc. Vladimira Vuletić, dr. sc. Andrea Dekanić

Voditeljica radionice: doc. dr. sc. Nina Pereza

Suradnici: prof, dr. sc. Saša Ostojić, Evgenia Arh, Andrej Belančić, Damir Vučinić

\section{PROGRAM}

Petak, 9. ožujka

ANALIZA PRIKAZA SLUČAJA KAO VRSTE ZNANSTVENOG ČLANKA

16.00 - 16.45 Vrste znanstvenih djela. Kriteriji za pisanje prikaza slučaja. 16.45 - 17.30 Struktura prikaza slučaja. Organizacijske sastavnice teksta. 17.30 - 18.00 Pauza za kavu

18.00 - 18.45 Struktura i funkcija sažetka

18.45 - 19.30 Struktura i funkcija naslova i ključnih riječi

Subota, 10. ožujka

SMJERNICE ZA PISANJE PRIKAZA SLUČAJA

09.00 - 09.45 Izrada vremenske crte

09.45 - 10.30 Predložak za pisanje prikaza slučaja i kontrolna lista

10.30 - 10.45 Pauza za kavu

10.45 - 11.30 Specifičnosti znanstvenog jezika u prikazu slučaja

11.30 - 12.00 Upute znanstvenog časopisa za pripremanje članka

12.00 - 12.15 Pauza za kavu

12.15 - 13.30 Baze podataka za pretraživanje literature 
su plod istraživanja unutar Fakulteta izvrsno su okružje za učenje i jamac isto takvog mentorskog potencijala. Stoga je vizija inicijative buđenja studentske znanosti u takvim uvjetima sve manje pojedinačni iskorak, a sve više prirodan tijek.

S obzirom na uspjeh Studentske sekcije u 2018. godini, želja nam je nastaviti s uspostavljenim ciljevima, ali i pokrenuti nove inicijative, većinom utemeljene na provođenju znanstvene edukacije među studentima. Potaknuta velikim interesom studenata za MedRi studentske znanstvene kongrese, Izvršna urednica pokrenula je i izborni kolegij Umijeće raščlanjivanja i sastavljanja u znanosti: izrada konferencijskih priopćenja i sažetaka znanstvenih članaka, koji bi trebao biti aktivan od 2019./2020. akademske godine na petoj godini integriranog preddiplomskog i diplomskog studija Medicina. Također, u pripremi je i niz tiskanih izdanja za studente, uključujući prvo izdanje brošure o uspješnoj organizaciji studentskih znanstvenih skupova, koja će sadržavati savjete i smjernice za organizaciju znanstvenih skupova prema pravilima dobre prakse, od određivanja vrste skupa koji se organizira do detalja te svakog od njih u ostvarenju čini posebnim i drugačijim, kao i strukturu zbornika sažetaka. Tiskanim izdanjima želimo na jednostavan, sustavan i studentima lako dostupan način omogućiti uvođenje niza noviteta za poboljšanje strategije vođenja studentske znanstvene aktivnosti kroz projekt FS4S - Fun Science for Students u suradnji s predstavnicima Medicinskog fakulteta u Rijeci i Znanstvenog odbora svih studenata (ZOSS). U viziji razvoja značajna je i inicijativa uspostave strukturne podloge za razvoj studentske znanosti, koja uključuje navedene aktivnosti povezane s časopisom Medicina Fluminensis, organizaciju i provođenje studentskih znanstvenih skupova, ali i bolju koordinaciju sa sveukupnom znanstvenom strategijom razvoja Medicinskog fakulteta. Tako je uspostavIjena nova funkcija Savjetnika za studentsku znanost, koji bi trebao koordinirati što bolju i konstruktivniju međusobnu suradnju ZOSS-a, Prodekana za znanost, organizatora studentskih znanstvenih skupova i časopisa Medicina Fluminensis, a sve s ciljem razvoja i promocije studentske znanosti.
ZAKLJUČAK - STUDENTI KAO NAJMLADI

STVARATELJI ZNANOSTI

Studentska je znanost najraniji trag i početak znanstvene aktivnosti na Medicinskom fakultetu. Ona se može ogledati u mnogobrojnim aktivnostima, čiji su začetnici i organizatori studenti, a koje će i u budućnosti pratiti i podržavati znanstvenici i nastavnici Medicinskog fakulteta u Rijeci, kroz mentorstva, superviziju ili aktivno

Na temelju iznimnog uspjeha prve godine djelovanja Studentske sekcije, velikog interesa, broja i kvalitete pristiglih znanstvenih članaka, redoviti tematski broj posvetili smo studentima. lako se studenti često susreću s predrasudama o slabijoj kvaliteti svojih članaka i manje strogim kriterijima za objavu, u našem časopisu otvorili smo mogućnost rane edukacije o suradnji sa znanstvenim časopisima kao posebnom obliku komunikacije u znanosti, poštovanjem istovjetnih uvjeta recenzijskog postupka kao i za ostale autore.

Medicinski fakultet u Rijeci institucija je s izrazito kvalitetnom znanstvenom produkcijom i infrastrukturom, prepoznatljivim znanstvenim grupama i pojedincima, što čini izvrsno okružje za učenje, a istovremeno je i jamac podjednakog mentorskog potencijala. Svim inicijativama želimo u studentima probuditi žar za znanošću koja je istovremeno životna i primjenjiva uz postelju pacijenta.

sudjelovanje u organizaciji studentskih znanstvenih aktivnosti. Medicina Fluminensis također će nastaviti biti vjetar u jedra studentskom usavršavanju u znanosti, uz otvorena vrata studentima. Kroz suradnju i podršku Medicinskog fakulteta u Rijeci i Hrvatskoga liječničkog zbora - podružnica Rijeka nastavit ćemo razvoj i napredovanje studentske znanosti prema sustavno vođenoj, organiziranoj i kvalitetnoj aktivnosti dostupnoj svakom studentu voljnom da uz kontinuiran i dosljedan rad, na pravi i akademski način, ali ujedno kroz mentalnu igru i kreativnost stvaranja, stvori bolju i kvalitetniju osnovu za temelj svoje akademske i profesionalne budućnosti. Zato je potrebno znanost učiniti bliskom studentima, od imatrikulacije 
do promocije, ne čineći je dalekom i teškom, nego bliskom i pristupačnom. I, najvažnije, želimo približiti znanost studentima tako da ona ne bude daleka i nerazumljiva, već temeljena na dokazima, ali primjenjiva uz postelju pacijenta.

Put kojim korača studentska znanost u budućnosti bit će svakako trnovit, ali vrijedan truda. Uz obilje dobrodošlih promjena i otvorenost prema idejama svih studenata, u suradnji sa svim prethodno navedenim dionicima, nastavit ćemo osluškivati i na što kvalitetniji način realizirati želje i potrebe studenata za stručnim i akademskim usavršavanjem, jer znanost je svakako jedna od rijetkih ljudskih tvorevina koja je univerzalna, činjenična $\mathrm{i}$ bez predrasuda te svugdje prisutna $\mathrm{i}$ dobrodošla. Ona predstavlja stabilan temelj, ali ujedno i dobar smjer plovidbe od brucoša do mladog liječnika. Kao i more, znanost može biti mirna i prostrana, ali i nepredvidiva i izazovna, što nam može biti poticaj da od malih nogu naučimo ploviti kroz njene valove, jer ono što je sigurno je da uz ulog vremena i truda pruža živopisno iskustvo i bogatstvo koje može živjeti dulje od nas samih.

doc. dr. sc. Nina Pereza, dr. med., prof. dr. sc. Saša Ostojić, dr. med., Andrej Belančić, dr. med., Maja Ploh Sveučilište u Rijeci, Medicinski fakultet

\section{LITERATURA}

1. Medicina Fluminensis [Internet]. Rijeka: Medicinski fakultet Sveučilišta u Rijeci; c2014. Upute autorima; 2018 Dec [cited 2018 Oct 24]. Available from: https://www. medri.uniri.hr/hr/medicina-fluminensis/

2. CARE guidelines [Internet]. IMI LLC; c2018. [cited 2018 Oct24]. Available from: http://www.care-statement.org/ 